\title{
15. OXYGEN ISOTOPE GEOCHEMISTRY OF ROCKS FROM DSDP LEG 46
}

\author{
Karlis Muehlenbachs, Department of Geology, University of Alberta, Edmonton, Canada \\ and \\ Floyd N. Hodges, Department of Geology, Furman University, Greenville, South Carolina
}

\begin{abstract}
The oxygen isotopic compositions $\left(\delta^{18} 0\right)$ of basalts from DSDP Leg 46 range from 5.9 to $8.9 \%$ (SMOW), indicating 1 to 15 per cent weathering induced by cold sea water. Basalts from the bottom portion of the hole, including basaltic gravel, have lower $\delta^{18} 0$ than basalts from the upper parts of the hole, consistent with the bottom portion of the hole being sealed off from direct sea-water circulation prior to drilling. The $\delta^{18} 0$ $(34.7 \%)$ of vug-filling carbonate from the highly altered central portion of the 9-meter cooling unit in Core 15 indicates that the alteration is a result of cold sea-water reaction and is not deuteric alteration.
\end{abstract}

\section{INTRODUCTION}

Hole $396 \mathrm{~B}$ of Leg 46 (located at $22^{\circ} 59.14^{\prime} \mathrm{N}$, $43^{\circ} 30.90^{\prime} \mathrm{W}$, approximately $160 \mathrm{~km}$ east of the MidAtlantic Ridge) penetrated 205.5 meters into basement. Basement at the site consists primarily of basaltic pillow lavas and fragmental basaltic material, and is overlain by 150.5 meters of nannofossil ooze, the basal part of which is Miocene ( $\sim 13$ m.y.). The purpose of this paper is to report on the oxygen isotope geochemistry of samples from Site 396B and to relate that chemistry to interaction between basaltic basement material and ocean water.

Several studies have shown that the $\delta^{18} 0$ values of unaltered oceanic basalts are very uniform, approximately 5.7 $\pm 0.3 \%$ o (Taylor, 1968; Garlick and Dymond, 1970; Muehlenbachs and Clayton, 1972; Pineau et al., 1976: Anderson and Lawrence, 1976; and Muehlenbachs, 1976, 1977a). The same studies have shown that most ocean basalts are a few per mil enriched in ${ }^{18} 0$ because of partial reaction with cold sea water. Consideration of basaltic dredge samples and a wide range of DSDP samples indicates that there is a high positive correlation between the $\delta^{18} 0$ of the basaltic samples and their total water content Muehlenbachs and Clayton, 1972; Pineau et al., 1976; Muehlenbachs, 1977 a,b). Thus, to a good approximation the samples may be considered as mixtures of normal- $\delta^{18} 0$ $(\sim 5.7 \% 0)$, fresh, anhydrous basalt and high- $\delta^{18} 0(\sim$ $27 \%$ ) smectites formed during weathering at low temperatures $\left(\sim 4^{\circ} \mathrm{C}\right)$, and the percentage of oxygen isotope exchange experienced by the sample is a direct measure of the degree of weathering the sample has undergone.

Samples recovered by DSDP Legs 34, 37 (Muehlenbachs, 1976, 1977a), and 46 (this study) are approximately 10 per cent weathered, more or less uniformly to a depth of at least 580 meters into the basaltic layer of the relatively young oceanic crust. Isotopic evidence indicates that both dredge samples of similar age (Muehlenbachs and Clayton, 1976) and the Cretaceous and Jurassic basalts recovered by DSDP Legs 11, 26, 27 (Muehlenbachs, 1977b), and 35
(Anderson and Lawrence, 1976) are considerably more weathered than samples from Legs 34, 37, and 46.

\section{METHODS}

Oxygen was extracted from the rock powders by the $\mathrm{BrF}_{5}$ method (Clayton and Mayeda, 1963), reacted with carbon to form $\mathrm{CO}_{2}$, and analyzed on an isotope ratio mass spectrometer. The isotopic composition of sample, $x$, is given:

$$
\delta_{\mathrm{x}}=\frac{{ }^{18} 0 /{ }^{16} 0 \mathrm{x}}{{ }^{18} 0 /{ }^{16} 0 \text { standard }}-1 \times 1000 .
$$

The analyses are reported relative to Standard Mean Ocean Water (Craig, 1961). The carbonates were analyzed by the $\mathrm{H}_{3} \mathrm{PO}_{4}$ method (McCrea, 1950).

\section{OXYGEN ISOTOPE GEOCHEMISTRY}

The values of $\delta^{18} 0$ for ten basaltic and two carbonate samples for DSDP Hole 396B are presented in Table 1. The $\delta^{18} 0$ values for basalts range from $5.9 \%$ for a pillow rind fragment from the lower part of the hole $(26-1,3-7 \mathrm{~cm})$ to $8.9 \%$ for an iron oxide stained sample from the vuggy interior of the 9-meter cooling unit in Core 15 (15-3, 83-89 $\mathrm{cm})$. Although water contents are not presently available for these samples, on the reasonable assumption that these samples fall on the same trend as other deep-sea samples, the measured $\delta^{18} 0$ values represent from 1 to 15 per cent weathering, with an average value of approximately 9 per cent. The amount of weathering indicated for the Leg 46 basalts is quite comparable to that found for other young crustal samples such as those from Legs 34 and 37 (Muehlenbachs, 1976, 1977a) and is considerably less than the approximately 50 per cent weathering indicated for Cretaceous and Jurassic samples from DSDP Legs 11, 26, 27, and 35 (Muehlenbachs, 1977b; Anderson and Laurence, 1976).

The two carbonate samples analyzed are both highly enriched in ${ }^{18} 0$ (Table 1). Carbonate cement from a pillow 
TABLE 1

${ }_{\delta^{18}} \mathrm{O}(\mathrm{SMOW})^{\mathrm{a}}$ of Samples From DSDP Leg 46

\begin{tabular}{|c|c|c|c|}
\hline $\begin{array}{c}\text { Sample } \\
\text { (Interval in } \mathrm{cm} \text { ) }\end{array}$ & $\begin{array}{l}\text { Basalt } \\
\delta^{18} \mathrm{O}\end{array}$ & $\begin{array}{c}\text { Carbonate } \\
\delta^{18} \mathrm{O}\end{array}$ & $\begin{array}{c}\text { Carbonate } \\
{ }_{\delta}^{13} \mathrm{C} \\
(\mathrm{PDB})^{\mathrm{a}}\end{array}$ \\
\hline $\begin{array}{l}396 \mathrm{~B}-5-1,63-68 \\
396 \mathrm{~B}-7-1,50-57^{\mathrm{b}} \\
396 \mathrm{~B}-11-1,22-28 \\
396 \mathrm{~B}-15-2,120-123^{\mathrm{c}} \\
396 \mathrm{~B}-15-3,83-89 \\
396 \mathrm{~B}-20-5,12-20 \\
396 \mathrm{~B}-22-3,28-38^{\mathrm{d}} \\
396 \mathrm{~B}-26-1,3-7 \\
396 \mathrm{~B}-32-1,100-105 \\
396 \mathrm{~B}-33-1,60-65^{\mathrm{e}}\end{array}$ & $\begin{array}{l}8.5 \\
6.5 \\
8.2 \\
7.8 \\
8.9 \\
8.5 \\
7.9 \\
5.9 \\
7.0 \\
6.7\end{array}$ & 34.5 & +1.9 \\
\hline
\end{tabular}

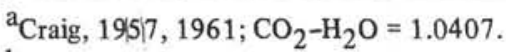

${ }^{b}$ Leg 46 internal chemical standard 1.

${ }^{\mathrm{c}}$ Leg 46 internal chemical standard 2.

${ }^{d}$ Leg 46 internal chemical standard 3.

${ }^{\mathrm{e}}$ Basaltic gravel.

breccia near the top of the basalt sequence $(5-1,63-68 \mathrm{~cm})$ yields a $\delta^{18} 0$ of $34.5 \%$ and calcite from vugs in cooling unit Sample $15-3,83-89 \mathrm{~cm}$ yields a $\delta^{18} 0$ value of $34.7 \%$. If the carbonates are pure calcites in equilibrium with normal sea water, their isotopic composition implies a temperature of $-3^{\circ} \mathrm{C}$ (O'Neil et al. 1969), a value within the range of $7^{\circ}$ to $-10^{\circ} \mathrm{C}$ calculated for carbonates from Legs 34 (Seyfried et al, 1976), 37 (Muehlenbachs, 1977a), and for dredged basalts (Muehlenbachs and Clayton, 1972). The indicated sub-freezing temperature is probably a result of the presence of divalent cations other than calcium in the carbonates.

The basaltic samples in the upper part of the hole (Cores 5 to 22), with the exception of Sample 7-1, 50-57 cm, are more enriched in ${ }^{18} 0$ than the three analyzed samples from the lower part of the hole (from Cores 26, 32, and 33). Sample 7-1, 50-57 cm, one of the Leg 46 internal chemical standards, evolved a considerable quantity of water during grinding in a ball mill (M. Dungan, written communication) and probably has not yielded a meaningful $\delta^{18} 0$ value. Ignoring this sample, the average $\delta^{18} 0$ for the upper six basaltic samples is $8.3 \%$ with a standard deviation of $0.4 \%$, while the average value for the lower three samples, including basaltic gravel Sample $33-1,60-65 \mathrm{~cm}$, is $6.5 \%$ with a standard deviation of 0.6 . The lower $\delta^{18} 0$ values in the bottom portion of the hole are indicative of less interaction with sea water and are consistent with heat flow evidence that the bottom portion of the section at Hole 396B was sealed off from direct sea-water circulation prior to drilling of the hole (Erickson, this volume).

Two samples from the 9-meter cooling unit in Core 15 were analyzed, one from the relatively fresh upper portion of the unit and one from the vuggy, iron-oxide stained central portion. Sample $15-3,83-89 \mathrm{~cm}$, from the central portion has a higher $\delta^{18} 0(8.9 \%$ than Sample $15-2,120-123$ $\mathrm{cm}(7.8 \%)$, consistent with the more altered appearance of the former. In addition, the $\delta^{18} 0(34.7 \% 0)$ of the vug-filling carbonate from Sample 15-3, $83-89 \mathrm{~cm}$, is a strong indica- tion that the alteration in that sample is a result of reaction with cold sea water rather than deuteric alteration.

\section{CONCLUSIONS}

The major conclusions that may be drawn from this study are: (1) samples from DSDP Hole 396B exhibit $\delta^{18} 0$ values similar to those from other young crustal samples that have undergone low-temperature reaction with sea water; $(2)$ the lower $\delta^{18} 0$ values in the bottom portion of the hole are consistent with the lower clastic sequence being sealed off from direct cirulation of sea water prior to drilling; and (3) the $\delta^{18} 0$ values from vug filling carbonate in Sample 15-3, $83-89 \mathrm{~cm}$, indicates that the more intense alteration in the central portion of the 9-meter cooling unit is a result of low-temperature reaction with sea water rather than deuteric alteration.

\section{REFERENCES}

Anderson, T.F. and Lawrence, J.R., 1976. Stable isotope investigations of sediments, basalts and authigenic phases from Leg 35 cores. In Hollister, C.D., Craddock, C., et al., Initial Reports of the Deep Sea Drilling Project, Volume 35: Washington (U.S. Government Printing Office), p. 497-505.

Clayton, R.N. and Mayeda, T.K., 1963. The use of bromine pentafluoride in the extraction of oxygen from oxides and silicates for isotopic analysis, Geochim. Cosmochim. Acta, v. 27, p. 43-52.

Craig, H., 1957. Isotopic standards for carbon and oxygen and correction factors for mass-spectrometric analysis of carbon dioxide, Geochim. Cosmochim. Acta, v. 12, p. 133-149.

1961. Standard for reporting concentrations of deuterium and oxygen-18 in natural waters, Science, v. 133, p. 1833-1834.

Garlick, D.G. and Dymond, J.R., 1970. Oxygen isotope exchange between volcanic materials and ocean water, Geol. Soc. Am. Bull., v. 81, p. 2137-2143.

McCrea, J.M., 1950. On the isotopic chemistry of carbonates and a paleo-temperature scale, J. Chem. Phys., v. 18, p. 849-857.

Muehlenbachs, K., 1976. Oxygen isotope geochemistry of DSDP Leg 34 basalts. In Yeates, R.S., Hart, S.R., et al., Initial Reports of the Deep Sea Drilling Project, Volume 34: Washington (U.S. Government Printing Office), p. 337-339. 1977a. Oxygen isotope geochemistry of rocks from DSDP Leg 37, Canadien J. Earth Sci., v. 14, p. 771-776. , 1977b. Low temperature oxygen isotope exchange between the oceanic crust and sea water, second Intern. RockWater Interaction Conf., Strassburg. p. 1317-1326.

Muehlenbachs, K. and Clayton, R.N., 1972. Oxygen isotope studies of fresh and weathered submarine basalts, Canadian J. Earth Sci., v. 9, p. 172-184.

O'Neil, J.R., Clayton, R.N., and Mayeda, T.K., 1969. Oxygen isotope fractionation in divalent metal carbonates, $J$. Chem. Phys., v. 51, p. 5547-5558.

Pineau, F., Javoy, M., Hawkins, J.W., and Craig, H., 1976. Oxygen isotope variations in marginal basins and ocean ridge basalts, Earth Planet. Sci. Lett., v. 28, p. 299-307.

Seyfried, W.E., Shanks, W.C., and Bischoff, J.L., 1976. Alteration and vein formation in site 321 basalts. In Yeats, R.S., Hart, S.R., et al., Initial Reports of the Deep Sea Drilling Project, Volume 34: Washington (U.S. Government Printing Office), p. 385-392.

Taylor, H.P., Jr., 1968. The oxygen geochemistry of igneous rocks, Contrib. Mineral. Petrol., v. 19, p. 1-71. 